This PDF is a selection from a published volume from the National Bureau of Economic Research

Volume Title: Financial Sector Development in the Pacific Rim, East Asia Seminar on Economics, Volume 18

Volume Author/Editor: Takatoshi Ito and Andrew K. Rose, editors

Volume Publisher: University of Chicago Press

Volume ISBN: 0-226-38684-8

Volume URL: http://www.nber.org/books/ito_07-2

Conference Date: June 22-24, 2007

Publication Date: February 2009

Chapter Title: Did the Japanese Stock Market Appropriately Price the Takenaka Financial Reform?

Chapter Author: Masaya Sakuragawa, Yoshitsugu Watanabe

Chapter URL: http://www.nber.org/chapters/c0402

Chapter pages in book: $(317$ - 340) 


\title{
Did the Japanese Stock Market Appropriately Price the Takenaka Financial Reform?
}

\author{
Masaya Sakuragawa and Yoshitsugu Watanabe
}

\subsection{Introduction}

The financial crisis and nonperforming-loan problem effectively ended in 2005, after one decade since its onset. The Japanese government continued a policy of forbearance until October 2002, when the government released the aggressive financial reform, the so-called Takenaka Plan, in order to accelerate the disposal of nonperforming loans. The Takenaka Plan was remarkable in that it was the first reform in Japan that strongly requested that banks improve bank governance.

Bank governance becomes effective through market discipline and the government's supervision. Behind the release of the Takenaka Plan were undercapitalized banks and the weak supervision to accommodate them. The government continuously took a policy of forbearance that allowed banks to keep financing almost insolvent firms and to understate the amount of nonperforming loans. Minimum capital requirements had been formally introduced, but did not work effectively. A number of papers point out that the government allowed banks to engage in various accounting discretions in meeting capital requirements, including Ito and Sasaki (2002), Shrieves and Dahl (2003), Hosono and Sakuragawa (2003), Peek and Rosengren (2005), and Skinner (2005). The stock market also played little disciplinary role on bank governance.

What the government chose was to strengthen supervision to banks

Masaya Sakuragawa is a professor of economics at Keio University. Yoshitsugu Watanabe is a research associate at the Global Security Research Institute of Keio University.

We greatly appreciate our two referees, Takatoshi Ito and Randall Morck; Ken Koibuchi; Andrew Rose; and participants of East Asia Seminar on Economics held in Singapore and the eighth Macro-Conference held in Keio University. This project is supported by Nijyuuisseiki Bunka Gakujyutsu Zaidann. 
rather than to use market discipline. The Takenaka Plan strongly requested banks to accelerate the disposal of nonperforming loans and, hence, to improve the transparency of financial information. However, the perverse link of the stock market with the banking sector made things complicated. If investors thought the reform was too tough and reacted contagiously, it would have been difficult to implement the reform that requested banks meet capital requirements because Japanese banks held substantial amounts of equities so that they were vulnerable to declines in stock prices. The policymakers came to understand strongly the necessity for the policy coordination between the government and Bank of Japan (BOJ). In March 2003, the new governor of BOJ, Toshihiko Fukui, announced a package of monetary policies to accommodate the Takenaka Plan, including the continuation of the ample supply of liquidity to banks and an increase in the maximum amount of equity holdings that BOJ purchases from banks.

The purpose of this chapter is to study the market evaluation of the Takenaka Plan, using event study methodology. We investigate several financial events that occurred in 2002 and 2003, including the release of the Takenaka Plan, the announcement of the work schedule for implementing that plan, the release of a package of monetary policies, and the failures of Resona Bank and Ashikaga Bank. We hope to understand how market participants perceived the implementation of the Takenaka Plan through these events that will be closely related to the effectiveness of supervision to banks. For each of the events, we examine three questions. The first question is if the impact of each event on the stock market return is positive or negative to the banking sector as a whole. The second question is if the impact on the stock market return, if it exists, is uniform across banks, regardless of possible differences of the financial condition of individual banks. The third question is if the impact reflects more than pure contagion across banks, and if market participants differentiate the riskiness of individual banks by their financial conditions. The answer to the third question may uncover possible improvement of financial supervision.

We believe that the estimation for the market reaction to each event that occurred after the introduction of the Takenaka Plan contributes to evaluating the financial reform and bank governance in Japan. By estimating several events sequentially, we can investigate how market participants changed their expectation for the implementation of the financial reform over time. In addition, we can evaluate the role of the policy coordination by comparing estimations between, before, and after the monetary policy.

Brewer et al. (2003), a paper that is closely related to ours, estimate how the stock market prices financial conditions of individual banks for the failures of four commercial banks and two securities firms that occurred for the period from 1995 to 1998 . Their finding reports that to some extent the stock market incorporates information on financial conditions of individual banks into prices although the ability of the Japanese stock market 
to price the riskiness of financial firms was recognized to have been low due to the poor transparency of bank information. The methodology and some of financial variables used in the present analysis are common and comparable to theirs.

A number of other papers have studied the effectiveness of Japanese financial supervision using an approach of an event-study analysis. Peek and Rosengren (2001) study the government reaction to Japan's premium problem that occurred from 1995 to 1998 and report that the announcement by the government was not effective in the reduction of the premium, but capital injections to banks were effective. ${ }^{1}$ Spiegel and Yamori (2003) study the stock market response to two financial regulatory reforms passed in 1998, the Financial Reconstruction Act and the Rapid Recapitalization Act, and report that shareholders of regional banks responded favorably to the legislation of these acts, while those of large banks did adversely. Spiegel and Yamori (2004) argue that market participants perceive the financial supervisory policy as a too-big-to-fail policy, but that the tendency to favor large banks has been diminishing over time. Yamori and Kobayashi (2007) study the effect of the nationalization of Resona Bank on the stock market and report that as the government announces the protection of shareholders of Resona, market participants come to regard the injection of public funds for the nationalization as a too-big-to-fail policy.

This paper is organized as follows. Section 9.2 surveys the financial supervisory policy in Japan since 1998. Section 9.3 explains the methodology. Section 9.4 explains data. Section 9.5 reports the empirical results. Section 9.6 examines other related events. Section 9.7 concludes.

\subsection{Financial Supervisory Policy in Japan}

In 1997, three large financial institutions, Sanyo Securities, Hokkaido Takushoku Bank, and Yamaichi Securities, failed, and Japanese financial supervision came to the turning point. ${ }^{2}$ In July 1998, the Financial Supervisory Agency was founded as an independent agency of the fiscal authority, which was reorganized in June 2000 as Financial Services Agency (hereafter, FSA). In October 1998, two financial reforms, the Financial Reconstruction Act and the Prompt Recapitalization Act, were passed. These two acts were aimed to inject public funds into weak banks, to nationalize failing banks, and to protect depositors. Soon after their enactment, two major banks, the Long-Term Credit Bank of Japan and Nippon Credit Bank, were nationalized for insolvency. Financial supervision was formally arranged.

1. Ito and Harada (2004), since 2001, credit derivative swaps as a good indicator of Japanese bank risk.

2. See also Hoshi and Kashyap (2004), which is a good overview for the Japanese banking problem. 
In March 1998 and March 1999, the government injected public funds into large banks in an attempt to avoid a possible financial crisis and its associated economic stagnation. As figure 9.1 illustrates, just after the legislation of the Financial Reconstruction Act done in October 1998, the stock market rapidly recovered. The stock market seems to have priced the de facto establishment of financial supervision favorably.

In January 1999, Mr. Yanagisawa was appointed as financial supervisory minister. However, Minister Yanagisawa was conservative in the disposal of nonperforming loans and even opposed to the nationalization of banks for the reason that Japanese banks were recovering. The FSA started to inspect bank assets in order to promote the disposal of nonperforming loans. The FSA made the first-round special inspection from 2000 to 2001, reporting that the total amount of nonperforming loans disclosed by individual banks was 34 trillion and over, whereas the total amount made by the FSA inspection was 47 trillion and over. The gap amounted to 13 trillion yen. This observation suggests that even after the legislation of the two acts for financial reforms, the FSA did not evaluate bank assets accurately.

The government continued a policy of regulatory forbearance in helping banks that were severely undercapitalized. In 1998, banks were allowed to account for "deferred tax assets" as Tier 1 core capital. Deferred tax assets are tax credits from past loses that banks expect to claim in the future. This accounting treatment of deferred tax assets provided bank managers with much discretion on its estimation that should be subjective. Skinner (2005) reports that Japanese banks have used deferred tax assets to compensate for declines in bank capital that arose from unrealized losses on the holdings of stocks.

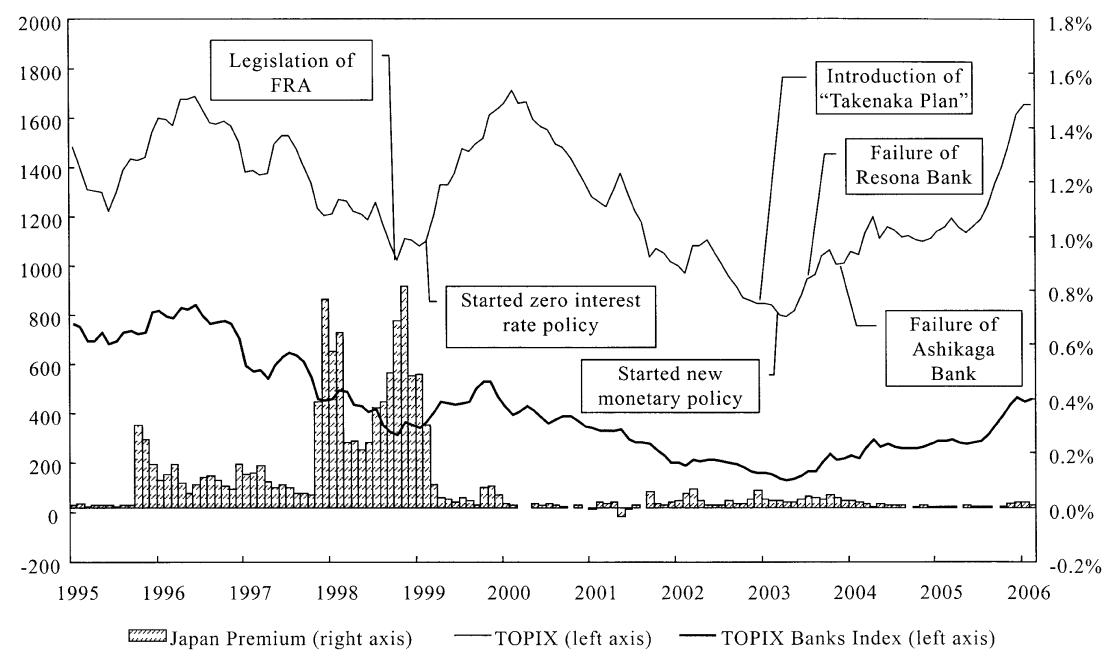

Fig. 9.1 Changes in stock price index and Japan premium 
Subordinated debt is allowed to account for as Tier 2 complementary capital in the Japanese local rule of capital requirements. In Japan, subordinated debt is, however, held mainly by insurance companies, while banks hold a significant amount of debt issued by insurance companies so that banks and insurance companies are under the relationship of "double gearing" (e.g., Fukao and the Tokyo Center for Economic Research [TCER] 2003). Consequently, subordinated debt was used as a tool of regulatory-capital arbitrage. Ito and Sasaki (2002) and Hosono and Sakuragawa (2002) report that banks with poor capital tended to issue more subordinated debt in order to inflate their bank capital.

Fukao and TCER (2003) estimate the "true" bank capital by excluding problematic capital from the regulatory capital and report that, as of March 2002, the true capital ratio in the Bank for International Settlements (BIS) standard amounted only to 1.36 percent even after including public funds injected as bank capital. The stock market also seems to have questioned the government's ability to supervise banks. Spiegel and Yamori (2003) report that market participants perceived the Financial Reconstruction Act as a tool of forbearance. These observations suggest that in the period of 1998 to 2002, the FSA had poor ability to supervise banks. Stock prices began to decline again in October 1999.

Bank of Japan continued monetary expansion in order to avoid further decline in stock prices and the consequent financial crisis. Despite the huge amount of liquidity supply, however, stock prices continued to decline.

In October 2002, Minister Yanagisawa had to take responsibility for a possible financial crisis and was replaced by Heizo Takenaka. He released the Financial Revitalization Program, the so-called, Takenaka Plan in order to accelerate the disposal of nonperforming loans. Behind this policy change was recognition that a continued policy of forbearance led to huge amounts of bad loans and nonperforming loans and made the stagnation severe and prolonged.

The regulatory forbearance in helping undercapitalized banks allowed banks to roll over loans to nearly insolvent firms (e.g., Hosono and Sakuragawa 2002; Peek and Rosengren 2005; and others). The subsidized lending led to credit misallocation from manufacturing firms with high productivity to nonmanufacturing firms with low productivity (e.g., Caballero, Hoshi, and Kashyap 2003). The "evergreen" has been recognized to be one important source of the slowdown of economic growth in the Japanese economy.

At the end of November 2002, the government announced the detailed work schedule for implementing the Takenaka Plan. The Takenaka Plan had three main parts. First, the government requested banks to disclose the amount of nonperforming loans on a stricter standard than before. Second, the government stopped a policy that allowed banks to engage in regulatory-capital arbitrage for meeting minimum capital requirements. 
Specifically, the government requested banks not to overstate deferred tax assets as bank capital. Third, the government arranged a scheme for injecting public funds into weak but solvent banks by adopting the Deposit Insurance Law, Article 102 that is intended to help banks in order to prevent a possible financial crisis.

The government appealed strongly for the implementation of the financial reform, but some observers have been disappointed with the announced work schedule. Before the release of work schedule, the tighter schedule of assessment rules on deferred tax assets was expected but remained unspecified. In addition, the detailed rule for applying Deposit Insurance Law was expected but not settled. To the end of this year, stock prices continued to decline.

In early 2003, the persistent decline in stock prices continued. The government came to fear a possible financial crisis that might be triggered by the decline in stock prices. Japanese banks were vulnerable to stock market risk because they held substantial amounts of equities. The policymakers came to understand strongly the necessity of strengthening policy coordination between the government and BOJ.

On March 25, 2003, the new governor of BOJ, Toshihiko Fukui, announced a package of new monetary policies. New policies had three main parts: first, BOJ continued the ample supply of liquidity to banks; second, BOJ applied the Lombard-type lending facility to the official discount rate by suspending the restriction on the maximum number of days; and third, BOJ extended the maximum amount of equity holdings that BOJ purchases from banks from 2 trillion yen to 3 trillion yen. ${ }^{3}$ The third pillar is a so-called nontraditional monetary policy that was intended to interrupt the transmission of risk from the stock market to the banking sector. ${ }^{4}$ The stock market got out of the bottom in March.

In May 2003, the failure of Resona, one of the Japanese largest banks, was revealed. This failure was triggered by its auditors who did not agree to the excessively estimated deferred tax assets, but requested the write-off of part of these assets. The capital ratio on the BIS standard was reported to be about 2 percent at the earnings report as of March 2003, below the minimum requirement for ordinary domestic operation of 4 percent. An immediate emergency meeting of the Government's Financial Service Management Council, headed by Prime Minister Koizumi, decided a subsequent massive injection of public funds following the Deposit Insurance Law, Article 102-1-1. The bankruptcy proceeding following Article 102-1-1 involves the injection of public funds and the restructuring by the government initiative. This procedure is not followed by liquidation, unlike in the

3. Governor Fukui stated before the press that BOJ was ready for purchasing all the equities held by banks if the worst scenario came.

4. On November 29, 2002, BOJ implemented the first-round purchase of equities from banks. 
case of Long-Term Credit Bank of Japan and Nippon Credit Bank. Article 102-1-1 is applied to a failing bank whose net asset is positive, but a possible negative net asset for Resona was revealed from the FSA inspection done later.

Just two days following the announcement of nationalization, the government, fearing a possible decline in stock prices, announced protection for the existing shareholders of Resona. Some observers criticized the government's statement for the reason that this policy weakens market discipline. Although the unclear government attitude led to much controversy, stock prices apparently reversed the trend upward in May.

The FSA pursued Ashikaga Bank, one of the largest regional banks, and disclosed the inappropriate loan classification, the shortage of loan loss reserves, and the overstatement of differed tax assets of that bank. The net asset of Ashikaga was reported to be negative in the earning report as of September 2003. Using this report, November 29, 2003, an immediate emergency meeting of the Government's Financial Service Management Council decided on a subsequent injection of public funds following Deposit Insurance Law, Article 102-1-3. The bankruptcy proceeding following Article 102-1-3 involves the acquisition of all stocks at zero by the government while protecting all deposits, the restructuring on the government initiative, and the sale of bank assets to other banks. Unlike the case of Resona, shareholders bear the substantial costs. Stock prices kept the upward trend.

From 2003 to 2004, the FSA conducted the third-round special inspection. The total amount of nonperforming loans disclosed by individual banks was 34 trillion and over, while the total amount by the FSA inspection was 36 trillion and over, and the discrepancy reduced to 2 trillion yen. This observation seems to reveal that the financial supervision improved to some extent.

By the introduction of the Takenaka Plan, the accuracy of evaluating bank assets and the transparency of financial conditions seems to have improved, but the market reaction to each individual event varied. In the following, we examine the market response to the Takenaka Plan using an event-study approach.

\subsection{Methodology}

In this section, we examine three important events that occurred in 2003, the release of a package of monetary policies, and failures of Resona Bank and Ashikaga Bank. For each of the three events, we examine three questions. The first question is if the impact of each event on the stock price is positive or negative to the whole banking sector. The second question is if the impact on the stock market return, if it exists, is uniform across banks, regardless of possible differences of financial conditions or other charac- 
teristics of individual banks. The third question is if the impact reflects more than pure contagion, and if market participants differentiate the riskiness of individual banks by their financial conditions.

The estimation basically takes the form:

$$
R_{i t}=\alpha_{i}+\beta_{i} R_{m t}+\sum_{k=0}^{1} \gamma_{i k} D_{k}+\varepsilon_{i t},
$$

where $R_{i t}$ is the stock return of bank $i$ on day $t ; \alpha_{i}$ is the intercept coefficient for bank $i ; R_{m t}$ is the market index for day $t ; \beta_{i}$ is the market risk coefficient for bank $i ; D_{k}$ is a binary variable that equals 1 if day $t$ is equal to the event day or window $k \in[0,+1]$, zero otherwise; $\gamma_{i k}$ is the event coefficient for bank $i$; and $\varepsilon_{i t}$ is a random error. Thus, the estimated parameters $\gamma_{i k}$ capture any daily intercept shifts on event day (window) $k$ and provide an estimate of abnormal (excess or unexpected) returns associated with the event announcement on day (window) $k$.

Each of events occurred on the same day for all the banks. It is likely that the abnormal returns are correlated contemporaneously among the individual banks. Thus, we do not estimate each of individual equations independently, but estimate equation (1) as a system of separate equations in the sample using generalized least squares (GLS). ${ }^{5}$ To permit the variance of the residuals to vary across banks, we apply seemingly unrelated regression (SUR). ${ }^{6}$

The values of the parameters in equation (1) are estimated using daily data before and after each event date over an observation period sufficiently long to obtain meaningful results. However, because the three events that

5. When the abnormal returns in the individual banks have contemporaneous correlation with one another, there are two different approaches: the first is the "portfolio approach," in which the bank-level analysis can be applied to a portfolio into which the abnormal returns are aggregated using event time. This approach has the advantage of allowing for crosscorrelation of the abnormal returns. The second is an application of a multivariate regression model with dummy variables for the event date. Comparing the two approaches, the latter methodology has the advantage of testing the null hypothesis that the event has no impact using individual bank data.

6. Because the events occurred on the same day for all the banks, it is likely that the residuals in the individual bank equations are correlated contemporaneously. Thus, we adjust for contemporaneous correlation. The methodology used in this article makes the standard assumptions that the residuals are independent and identically distributed within each equation and independent of the market return and the binary event variables; the noncontemporaneous correlation of residuals across banks is zero; and there is no event-induced heteroskedasticity. Thus, the covariance matrix of the residuals in equation (8) has the following structure:

$$
E\left(\varepsilon \varepsilon^{\prime}\right)=\left[\begin{array}{cccc}
\sigma_{1}^{2} I & \sigma_{12} I & \ldots & \sigma_{1 n} I \\
\sigma_{21} I & \sigma_{2}^{2} I & \ldots & \sigma_{2 n} I \\
\vdots & \vdots & \ddots & \vdots \\
\sigma_{n 1} I & \sigma_{n 2} I & \ldots & \sigma_{n}^{2} I
\end{array}\right],
$$

where $I$ is the identity matrix, and $N$ is the number of banks in the sample. 
occurred in 2003 are reasonably close to one another, we have to be careful to possible effects of a specific event on the subsequent events. To avoid this problem, following Brewer et al. (2003), equation (1) is modified so as to permit a shift in both the intercept $(\alpha)$ and the market index coefficient $(\beta)$ after the first event:

$$
R_{i t}=\alpha_{i}+\beta_{i} R_{m t}+\alpha_{i} P+\beta_{i} P R_{m t}+\sum_{e} \sum_{k=0}^{1} \gamma_{i k, e} D_{k e}+\varepsilon_{i t},
$$

where $e$ is the number representing each of events, the announcement of new monetary policy $(e=1)$, the failure of Resona $(e=2)$, and the failure of Ashikaga $(e=3) ; \gamma_{i k, e}$ is the coefficient for bank $i$ for the event $e(=1,2,3)$; and $P$ is a binary variable that is equal to 1 for the period after the first event window, the announcement of new monetary policy, and zero otherwise.

We first assess the impact of each event on the stock market return as a whole in the banking industry. In doing so, we test the following hypothesis using the estimated coefficients in equation (2).

$$
H_{0}^{\text {mean }}: \frac{1}{N}\left(\gamma_{1 k, e}+\gamma_{2 k, e}+\ldots+\gamma_{N k, e}\right)=0 .
$$

Equation (3) represents the hypothesis that the simple average of the individual abnormal returns is zero. If market participants perceive the impacts of each event favorably on the whole banking industry, the average will be positive, while otherwise, it will be negative. Be careful that large banks may have a great impact on the market price for the whole banking industry. To take into account the possible impacts of large banks, we test also the hypothesis with an asset-weighted coefficient.

$$
H_{0}^{W \text { mean }}: v_{1} \gamma_{1 k, e}+v_{2} \gamma_{2 k, e}+\ldots+v_{N} \gamma_{N k, e}=0,
$$

where $v_{i}$ is the weight on bank $i$ that is calculated by dividing the total market value of bank $i$ by the sum of total market values of all banks. Additionally, in order to compute the cross-sectional median of abnormal returns, we test the hypothesis that the number of banks with positive abnormal returns is greater than 50 percent in the sample:

$$
H_{0}^{\text {median }}: \text { median }=0 .
$$

If market participants perceive the impacts of each event favorably, the median is expected to be positive, while otherwise, it is expected to be negative. For testing this hypothesis, we compute the $t$-test statistic and check the sign test.

Second, we test the pure contagion hypothesis by assessing if the impact of each of the events is equal across all banks. We examine the following hypothesis

$$
H_{0}^{A R}: \gamma_{1 k, e}=\ldots=\gamma_{N k, e}
$$


Equation (6) represents the hypothesis that the coefficients of the individual abnormal returns in the sample are equal across banks. If shareholders differentiate the riskiness of individual banks, the hypothesis is rejected, while otherwise, the pure contagion hypothesis will be supported. For testing this hypothesis, we compute the standard asymptotic $\chi^{2}$ test statistic and the $F$-statistic.

Third, given that the pure contagion hypothesis is rejected, we test if the evidence of cross-sectional variation reflects their own financial conditions. In doing so, we expand equation (2) to include a number of conditioning variables that reflect financial characteristics of each bank and two other control variables:

$$
\begin{aligned}
R_{i t}= & \alpha_{i}+\beta_{i} R_{m t}+\alpha_{i} P+\beta_{i} P R_{m t}+\sum_{e} \bar{\gamma}_{k e} D_{k e}+\sum_{e} \phi_{e} D_{k e} \mathrm{COND}_{i} \\
& +\sum_{e} \theta_{e} D_{k e} \mathrm{SH}_{i}+\sum_{e} \lambda_{e} D_{k e} \mathrm{TA}_{i}+\mu_{i t},
\end{aligned}
$$

where $\bar{\gamma}_{k e}$ is the coefficient for all banks for the event $e(=1,2,3)$; $\mathrm{COND}_{i}$ is a variable that describes the financial condition of bank $i$ at the time of the event and is explained in detail in the following; $\mathrm{TA}_{i}$ is the log of total assets for bank $i$ at the time of the event, and controls for bank size; and $\mathrm{SH}_{i}$ is a variable that measures the shareholding between banks and controls for the exposure of bank $i$ to the failed bank through equity holding. ${ }^{7}$ The positive coefficient of $\mathrm{TA}_{i}$ may reveal the evidence of a too-big-to-fail policy. If the response of the stock market to the event reflects individual bank conditions, the coefficient of either $\mathrm{COND}_{i}$ or $\mathrm{SH}_{i}$ is statistically different from zero. We test the following hypotheses:

$$
H_{0}^{\text {cond }}: \phi_{e}=0 \text {, }
$$

and

$$
H_{0}^{\mathrm{SH}}: \phi_{e}=0,
$$

for each of the three events and a number of measures of $\mathrm{COND}_{i}$ and $\mathrm{SH}_{i}$. The coefficient of $\mathrm{SH}_{i}, \theta_{e}$, may reflect the government's attitude toward the existing shareholders of the failed bank. If shareholders bear substantial costs in the event of bank failure, the coefficient of $\mathrm{SH}_{i}$ is expected to be significant and negative.

We investigate nine descriptive variables as representing financial conditions of banks: (1) the ratio of nonperforming loans to total loans outstanding (NPL); (2) the ratio of reported loan loss reserves to riskweighted regulatory capital (LLR); (3) the ratio of domestic loans to firms

7. The variable $\mathrm{SH}_{i}$ is defined as $\mathrm{SH}_{i}=\rho_{i} \mathrm{TA}_{i} / \mathrm{TA}_{i}$, where $\rho_{i}$ is the percent of outstanding shares of the failed institution $j$ that was owned by bank $i$, TA is the total assets of the failed institution $j$, and $\mathrm{TA}_{i}$ is the total assets of the surviving bank $i$. 
in the three industries of construction, real estate, and finance and insurance, which are typically deemed to be riskier than other loans, to total domestic loans (RISKY); (4) the ratio of bank capital to total bank assets calculated based on either international or domestic standard (CAPITAL); (5) the ratio of subordinated debt to risk-weighted regulatory capital (SUB); (6) the ratio of deferred tax assets debt to risk-weighted regulatory capital (DEF); (7) the ratio of liquid assets to total bank assets (LIQ); (8) the ratio of the market value of stocks to total bank assets (STO), and (9) the ratio of the latent gains (losses) of stocks to total bank assets (GAIN).

If the disclosure of nonperforming loans by banks is accurate, banks with high values of NPL are then supposed to be financially weak. The marginal impact of each event is expected to be greater for banks with a higher NPL, and the sign is expected to be positive $\left(\phi_{1}>0\right)$ for the announcement of new monetary policy and negative $\left(\phi_{2}<0, \phi_{3}<0\right)$ for failures of banks. Loan loss reserves are, in principle, provisions for nonperforming loans so that banks that hold a higher number of nonperforming loans should account for greater loan loss reserves and, thus, should be associated with a higher value of LLR. The expected signs are the same as NPL so that $\phi_{1}>0, \phi_{2}<0$, and $\phi_{3}<0$.

As we have discussed extensively in section 9.2, however, it has been widely believed that nonperforming loans were understated. If the stock market incorporated this information into pricing, the two variables, NPL and LLR, may not appropriately reflect the soundness of banks. As a complementary variable, we use RISKY. A number of works, including Hoshi (2000), Sakuragawa (2002), and Hosono and Sakuragawa (2002), report that banks helped many of nearly bankrupt firms in the three industries of construction, real estate, and finance and insurance by rolling over loans to them. Banks should account for loan loss reserves against loans extended to these almost bankrupt firms, but they could dress up their balance sheets by classifying these problem loans as good because the FSA did not inspect nonperforming loans closely. For this reason, we use RISKY as a proxy to potential nonperforming loans. Banks with a higher value of RISKY tend to hold a higher number of nonperforming loans. The expected signs are $\phi_{1}>0, \phi_{2}<0$, and $\phi_{3}<0$.

We consider variables that capture the effect of minimum capital requirements. Banks with a smaller value of CAPITAL tend to be constrained more severely by capital requirements and will be affected more strongly by each of the events. The expected signs are $\phi_{1}>0, \phi_{2}<0$, and $\phi_{3}<0$.

As explained in section 9.2, the government implicitly allowed banks to use subordinated debt and deferred tax assets as tools of regulatory-capital arbitrage for meeting capital requirements. We use SUB and DEF as measures of regulatory-capital arbitrage in meeting capital requirements. Banks with a higher value of SUB or DEF will be perceived as banks that 
relied more on subordinated debt because they had scarce true capital. Those banks will be affected more strongly by each of the events. The expected signs for SUB and DEF are $\phi_{1}>0, \phi_{2}<0$, and $\phi_{3}<0$.

The variable LIQ is expected to have a great impact at the event of the package of new monetary policy. If shareholders think that the shortage of liquidity is a serious banking problem, an announcement for monetary expansion should affect stock prices favorably. Banks with a lower value of LIQ are more likely to suffer from the liquidity shortage and will be affected more strongly by the monetary expansion. The expected sign is $\phi_{1}<0$.

The variables STO and GAIN are expected to capture the influence of the change in stock prices on banks. Purchasing stocks by BOJ is supposed to weaken the adverse effect of the stock market decline on banks. Banks with a higher value of STO tend to be more vulnerable to the stock market risk and will be affected more favorably by this policy. The expected sign is positive $\left(\phi_{1}>0\right)$. Banks with greater losses of stock holding tend to be more vulnerable to the stock market risk and will be affected more favorably by this policy. The expected sign is negative $\left(\phi_{1}<0\right)$.

The stock price of banks that hold a greater proportion of the stock of the failed bank is expected to decline more sharply. The coefficients of $\mathrm{SH}_{i}$ are expected to be $\theta_{2}<0$ and $\theta_{3}<0$.

\subsection{Data}

Daily stock prices and returns for our sample of eighty publicly traded and surviving banks are obtained from the Toyo Keizai Kabuka CD-ROM for 307 business days from October 1, 2002 to December 30, 2003. All dates are Japanese dates. Market returns are measured by the TOPIX index, which includes seasoned shares of over 1,000 major companies including both banks and nonbanks (First Section) traded on the Tokyo Stock Exchange, from the CD-ROM of the Toyo Keizai Inc.'s stock price database. The data on the financial condition of individual banks are obtained from the Nikkei NEEDS financial statement database.

For financial data of individual banks, we use the earning reports released as of March 2003. The announcement dates of new monetary policy and the two failures are obtained through a search of the statement released by BOJ and a search of the Nihon Keizai Shimbun. Actually, BOJ announced a package of new monetary policies on March 25, 2003. At this stage, earning reports as of March 2003 were not yet released, but banks usually released the prediction of their earning in the interim period. It will be conceivable to think that market participants use this information in order to form the expectation on the financial condition of individual banks.

If each announcement is made during a trading day in Japan, that date is used as the event day. If an announcement was made after the market was closed or over the weekend, we use the next trading date as the event date. 
Following this criterion, we set the event days of the release of a package of monetary policies as March 25, 2003, the failure of Resona Bank as May 19, 2003, and the failure of Ashikaga Bank as December 1, 2003.

The number of banks used in the analysis is eighty for which stock market data is available, except for Resona and Ashikaga, both of which are excluded from the sample to avoid the survivorship bias. Note that in this sample period, a number of large banks are established by merger. We exclude Mitsui-Sumitomo Bank that is established by the merger of Sumitomo Bank and Sakura Bank for the reason that the stock market data is available only after November 29, 2002.

\subsection{Empirical Results}

Table 9.1 reports estimation results on equations (3), (4), and (5). The first column in the table reports the result for the estimated abnormal returns of individual banks for Day0 of each event window, the second column for Day +1 , and the third column for the $[0,+1]$ window.

For the new monetary policy, the first row, denoted, "Simple Mean," reports the average of the individual abnormal returns, and beneath the first row reports $t$-values. ${ }^{8}$ The average of abnormal stock market returns is positive and significant for Day0, negative and insignificant for Day +1 , and positive and significant for the $[0,+1]$ window. The third row, denoted, "Weighted Mean," reports the asset-weighted average of the individual abnormal returns and reports $t$-values beneath the third. The abnormal returns are positive and significant for Day0, negative and significant at the 10 percent level for Day +1 , and positive and significant for the $[0,+1]$ window. The two alternative estimations both seem to show that market participants perceive the monetary policy as favorable.

The row denoted "Median" reports the median of the abnormal returns of individual banks. The row denoted "Positive" reports the number of banks whose abnormal return is positive, and the row denoted "Negative" reports the number of banks whose abnormal return is negative. The row denoted "sign-test" reports $z$-values on the statistical significance for the median. On the event Day0, among eighty surviving banks, abnormal returns are positive for sixty-two banks, and the median is positive and significant. On the event Day +1 , the number of banks whose abnormal return is negative is more than a half (forty-six banks), and the median is

8. On November 29, 2002, BOJ implemented the first-round purchase of equities held by banks. But we do not examine this event because there were some reasons to support that some impacts of this policy were already incorporated into stock prices. For example, TOPIX shot up 1.66 percent on news that BOJ first announced the stock purchasing plan on September 18, 2002 and 3.32 percent on news that BOJ released "Stock Purchasing Guidelines" in October 11, 2002. On the other hand, it moved up only 0.52 percent on November 29, 2002. On the other hand, on the second-round purchase of equities, no information was leaked beforehand. 
Table 9.1

Abnormal returns of surviving banks

\begin{tabular}{|c|c|c|c|}
\hline & Day 0 & Day +1 & {$[0,+1]$} \\
\hline \multicolumn{4}{|c|}{ New monetary policy (March 25, 2003) } \\
\hline Simple mean & 0.011 & -0.001 & 0.01 \\
\hline$t$-statistic & $5.55^{* * *}$ & -0.51 & $4.09^{* * *}$ \\
\hline Weighted mean & 0.017 & -0.004 & 0.006 \\
\hline$t$-statistic & $2.62 * *$ & $-1.41^{*}$ & $2.37^{* *}$ \\
\hline Median & 0.011 & -0.002 & 0.011 \\
\hline Positive & 62 & 34 & 60 \\
\hline Negative & 18 & 46 & 20 \\
\hline Sign-test; $z$-statistic & $5.45 * * *$ & -0.79 & $4.56^{* * *}$ \\
\hline \multicolumn{4}{|l|}{$H_{0}: \gamma_{1}=\ldots=\gamma_{80}$} \\
\hline$F$-statistic & $2.61 * * *$ & $2.60 * * *$ & $5.21 * * *$ \\
\hline$\chi^{2}$-statistic & $208.92 * * *$ & $208.07 * * *$ & $416.51 * * *$ \\
\hline \multicolumn{4}{|c|}{ Failure of Resona Bank (May 19, 2003) } \\
\hline Simple mean & -0.011 & -0.004 & -0.015 \\
\hline$t$-statistic & $-5.95 * * *$ & $-2.00 * *$ & $-5.10^{* * *}$ \\
\hline Weighted mean & -0.015 & -0.006 & -0.011 \\
\hline$t$-statistic & $3.19 * * *$ & $-1.46^{*}$ & $-2.55^{* *}$ \\
\hline Median & -0.008 & -0.002 & -0.008 \\
\hline Positive & 16 & 32 & 20 \\
\hline Negative & 64 & 48 & 60 \\
\hline Sign-test; $z$-statistic & $-5.82 * * *$ & $-1.91^{*}$ & $-5.27^{* * *}$ \\
\hline \multicolumn{4}{|l|}{$H_{0}: \gamma_{1}=\ldots=\gamma_{80}$} \\
\hline$F$-statistic & $1.35^{* *}$ & $1.76^{* * *}$ & $3.16^{* * *}$ \\
\hline$\chi^{2}$-statistic & $108.23 * *$ & $141.50 * * *$ & $252.79 * * *$ \\
\hline \multicolumn{4}{|c|}{ Failure of Ashikaga Bank (December 1, 2003) } \\
\hline Simple mean & -0.013 & 0.008 & -0.004 \\
\hline$t$-statistic & $-4.64 * * *$ & $3.91 * * *$ & $-1.30^{*}$ \\
\hline Weighted mean & -0.019 & -0.002 & -0.011 \\
\hline$t$-statistic & $-2.16^{* *}$ & -0.33 & $-1.56^{*}$ \\
\hline Median & -0.007 & 0.006 & 0.002 \\
\hline Positive & 25 & 55 & 45 \\
\hline Negative & 55 & 25 & 35 \\
\hline Sign-test; $z$-statistic & $-4.94 * * *$ & $3.78 * * *$ & 0.15 \\
\hline \multicolumn{4}{|l|}{$H_{0}: \gamma_{1}=\ldots=\gamma_{80}$} \\
\hline$F$-statistic & $2.87 * * *$ & $1.89 * * *$ & $4.81^{* * *}$ \\
\hline$\chi^{2}$-statistic & $229.79 * * *$ & $151.75^{* * *}$ & $384.80^{* * *}$ \\
\hline
\end{tabular}

*** Significant at the 1 percent level.

**Significant at the 5 percent level.

*Significant at the 10 percent level.

negative but insignificant. On the two-day window, the median is positive and significant. The results for the three event days suggest that stockholders of banks evaluate new monetary policy favorably to the banking industry.

The estimation of the failure of Resona Bank shows that the row denoted "Simple Mean" reports that the average of the coefficients on the abnormal 
return is negative and significant in any of the three windows. The results on "Weighted Mean" also report that the average is negative and significant in any of the three. In more than half of the banks, abnormal returns are negative, and the medians are negative and significant in any of the three windows. Market participants seem to incorporate new information on Resona Bank negatively into stock prices.

On the other hand, for the failure of Ashikaga Bank, the row denoted "Simple Mean" reports that the average of the individual abnormal returns is negative and significant for Day0, but positive and significant for Day +1 . For the $[0,+1]$ window, the estimated value is negative but slightly significant. The results on "Weighted Mean" report that the average is negative and significant for Day0, and negative but insignificant for Day +1 . The results on the median report that the number of banks whose abnormal return is negative is more than half on the window [0], but less than half on the window $[+1]$.

In the case of Ashikaga, the average of the individual abnormal returns is positive for Day +1 . This finding is contrasted with the case of Resona in which the average abnormal stock returns are negative for both Day0 and Day +1 . In addition, the stock price of more than half the number of banks rises for Day+1. Market participants do not seem to perceive that the failure of Ashikaga transmits to other surviving banks. In other words, market participants may have anticipated the rapid government response.

Table 9.1 reports estimation results on equation (6). Rows beneath " $\mathrm{H}_{0}: \gamma_{1}=\ldots=\gamma_{80}=0$ " report the $\chi^{2}$-statistic and $F$-statistic. In any of the events, the pure contagion hypothesis is rejected. For each of the events, market participants seem to differentiate the riskiness of individual banks by financial condition and other characteristics.

We turn to the investigation for individual financial conditions. The upper part of table 9.2 reports estimation results for the event of new monetary policy. None of the financial variables is significant. Particularly, the coefficient of LIQ is expected to be significant, but it is insignificant. Neither STO nor GAIN is significant. Market participants perceive the monetary package as favorable to the whole banking industry, but they do not seem to regard it as a tool of differentiating banks by their conditions.

The central part of table 9.2 reports estimation results for the case of Resona. Among variables of financial conditions, RISKY, CAPITAL, DEF, and GAIN are significant. The statistical significance of CAPITAL and DEF will reveal that market participants came to perceive the Takenaka Plan as an effective tool to strengthen supervision. Particularly, the negative and significant coefficient of DEF will reflect the fact that the government did not allow Resona to overestimate differed tax assets as bank capital and finally nationalized Resona. Market participants seem to perceive that banks with greater deferred tax assets will be more severely disciplined through a stricter standard of capital requirements.

Neither NPL nor LLR is significant, while RISKY is significant. Market 


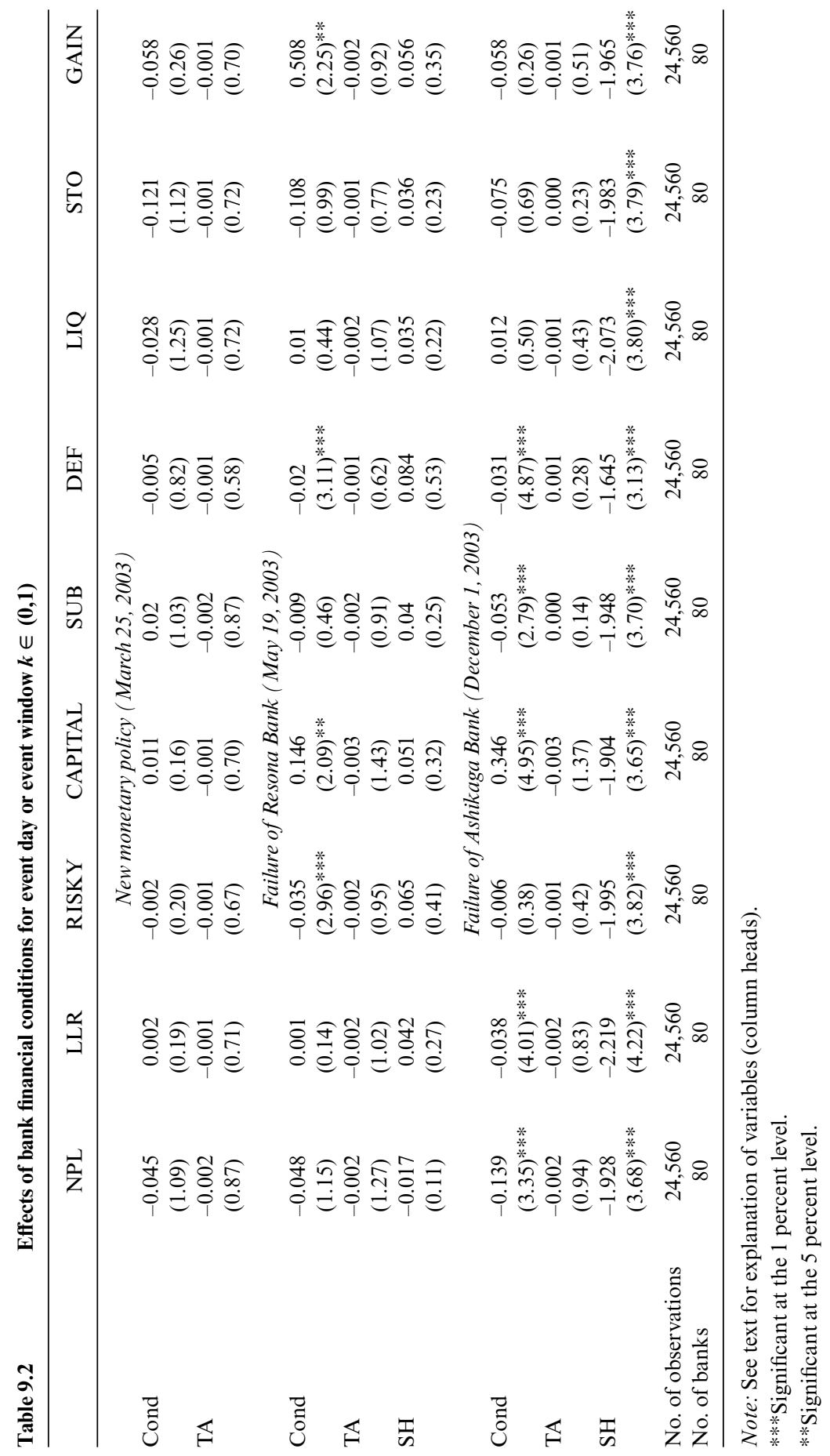


participants seem to perceive that nonperforming loans are still understated. Indeed, the government nationalized Resona by following Deposit Insurance Law, Article 102-1-1, which is intended to be applied to the bank whose net asset is positive, but later the FSA inspection detected a possible negative net asset of Resona. The measure of bank size, TA, is insignificant. We do not find any result to support for the too-big-to-fail policy. ${ }^{9}$ The variable $\mathrm{SH}$ is insignificant in all of the estimations. This result may reflect the fact that market participants accurately anticipated the protection of the existing shareholders of Resona following nationalization.

The lower part of table 9.2 reports estimation results for the case of Ashikaga. Among variables of financial conditions, five variables, NPL, LLR, CAPITAL, DEF, and SUB are significant. In terms of variables on nonperforming loans, NPL and LLR are significant. On the other had, RISKY is insignificant, while it is significant in the case of Resona. Market participants come to perceive that the FSA came to inspect nonperforming loans more accurately than before. In terms of variables on bank capital, DEF and SUB are significant. Market participants seem to perceive that the FSA came to force banks to meet capital requirements in a stricter standard. The variable $\mathrm{SH}$ is, unlike the case of Resona, negative and significant in all of the estimations. This result seems to reflect the fact that the government adopts the bankruptcy proceeding under which the existing shareholders bear the substantial costs. The variable TA is insignificant in all of the estimations.

Brewer et al. (2003) study a similar analysis using the failures of six financial institutions that occurred from 1995 to 1998, including Hyogo Bank, Sanyo Securities, Hokkaido Takushoku Bank, Yamaichi Securities, Long-Term Credit Bank of Japan, and Nippon Credit Bank. Four comparable variables of NPL, LLR, RISKY, and CAPITAL are used for their analysis and ours. Limiting cases on their four bank failures, the proportion of significant coefficients is about 31 percent (five among sixteen). On the other hand, the percentage rises to 63 percent in the present analysis. Market participants seem to perceive that the FSA supervision considerably improved after the introduction of the Takenaka Plan.

\subsection{Other Related Events}

In this section, we examine three other related events. The first event is the release of the Takenaka Plan, the second the announcement of the work schedule for implementing the Takenaka Plan, and the third is the announcement of the protection of existing shareholders of Resona Bank.

9. We never deny other possible methodologies to verify the evidence of a too-big-to-fail policy. For example, a nonlinear relationship between abnormal return and bank size might uncover the presence of a too-big-to-fail protection. 
We first examine the two events on the Takenaka Plan. We estimate equations (2) through (9) using the event day of the release of the Takenaka Plan as October 30,2002, and the event day of the announcement of work schedule for implementing the Takenaka Plan as November 28, 2002. ${ }^{10}$

Table 9.3 reports the estimation results for equations (3), (4), and (5). For the estimation of the release of the Takenaka Plan, the row denoted "Simple Mean" reports that the average of the individual abnormal returns is positive and significant in any of the three windows. The results on "Weighted Mean" also report that the average is positive and significant for Day 1 and the $[0,+1]$ windows. In more than half of the banks, abnormal return is positive, and the median is positive and significant in any of the three windows. Market participants seem to perceive the release of the Takenaka Plan as favorable.

On the other hand, for the announcement of schedule for implementing the Takenaka Plan, the row denoted "Simple Mean" reports that the average of the individual abnormal returns is negative and significant for Day0 and the $[0,+1]$ window. The results on "Weighted Mean" also report that the average is negative and significant for Day 0 and the $[0,+1]$ window. The results on the median report that the number of banks whose abnormal return is negative is more than half for Day0 and the $[0,+1]$ window. Market participants seem to be disappointed with the announced details of the work schedule.

Table 9.3 reports estimation results for equation (6). Rows beneath " $\mathrm{H}_{0}: \gamma_{1}=\ldots=\gamma_{80}=0$ " report the $\chi^{2}$-statistic and $F$-statistic. In any of the events, the pure contagion hypothesis is rejected. For each of the events, market participants seem to differentiate the influence of the Takenaka Plan on individual banks by financial conditions and other characteristics.

We turn to the investigation for individual financial conditions. For the event of the release of the Takenaka Plan, the upper part of table 9.4 reports estimation results. The measure of bank size, TA, has positive and significant coefficient in any of the estimations. This result may support the too-big-to-fail hypothesis. At first, market participants seem to be afraid if the financial reform is appropriately implemented. Among variables of financial conditions, NPL is significant but positive, contrasted sharply with the estimations of the three events examined in the previous section. On the release of the Takenaka Plan, market participants may have evaluated banks with great nonperforming loans as "strong" banks by conjecturing that strong banks can differentiate themselves from other banks by revealing the amount of nonperforming loans accurately. Behind this interpretation is that, as of 2002, it was widely believed that the number of nonperforming loans was understated.

10. We use daily stock prices data over 246 business days from January 4, 2002 to December 30,2002 . On financial data of individual banks, we use the earning reports released as of March 2002. 
Table 9.3

Abnormal returns of banks for release of the Takenaka Plan and announcement of work schedule

\begin{tabular}{|c|c|c|c|}
\hline & Day 0 & Day +1 & {$[0,+1]$} \\
\hline \multicolumn{4}{|c|}{ Release of Takenaka Plan (October 30, 2002) } \\
\hline Simple mean & 0.005 & 0.003 & 0.008 \\
\hline$t$-statistic & $2.36^{* *}$ & $1.64^{*}$ & $2.33^{* *}$ \\
\hline Weighted mean & 0.010 & 0.019 & 0.015 \\
\hline$t$-statistic & 1.00 & $1.76^{* *}$ & $1.59 *$ \\
\hline Median & 0.002 & 0.001 & 0.002 \\
\hline Positive & 50 & 43 & 50 \\
\hline Negative & 30 & 37 & 30 \\
\hline Sign-test; $z$-statistic & $1.86^{*}$ & 0.79 & $2.25^{* *}$ \\
\hline \multicolumn{4}{|l|}{$H_{0}: \gamma_{1}=\ldots=\gamma_{80}$} \\
\hline$F$-statistic & $1.81^{* * *}$ & $2.17^{* * *}$ & $3.99 * * *$ \\
\hline$\chi^{2}$-statistic & $145.08 * * *$ & $174.12 * * *$ & $319.20 * * *$ \\
\hline \multicolumn{4}{|c|}{ Announcement of work schedule (November 28, 2002) } \\
\hline Simple mean & -0.018 & 0.002 & -0.016 \\
\hline$t$-statistic & $-13.04^{* * *}$ & 0.93 & $-6.46^{* * *}$ \\
\hline Weighted mean & -0.016 & 0.000 & -0.008 \\
\hline$t$-statistic & $-5.00 * * *$ & 0.13 & $-3.16^{* * *}$ \\
\hline Median & -0.018 & 0.003 & -0.013 \\
\hline Positive & 5 & 49 & 16 \\
\hline Negative & 75 & 31 & 66 \\
\hline Sign-test; $z$-statistic & $-7.37 * * *$ & $1.89^{*}$ & $-5.92 * * *$ \\
\hline \multicolumn{4}{|l|}{$H_{0}: \gamma_{1}=\ldots=\gamma_{80}$} \\
\hline$F$-statistic & $1.88^{* * *}$ & $2.68^{* * *}$ & $4.76^{* * *}$ \\
\hline$\chi^{2}$-statistic & $151.16^{* * *}$ & $214.46^{* * *}$ & $381.24 * * *$ \\
\hline
\end{tabular}

*** Significant at the 1 percent level.

**Significant at the 5 percent level.

*Significant at the 10 percent level.

The lower part in table 9.4 reports estimation results for the event of the announcement of the work schedule. The variable TA is negative and insignificant. Among variables of financial conditions, two variables, CAPITAL and SUB, are significant. Market participants seem to have anticipated that the government took a first step to prevent banks from engaging in regulatory-capital arbitrage to meet minimum capital requirements. The variable DEF is insignificant. This result may reflect the fact that the time table of tightening assessment rules on deferred tax assets was still not specified. We have several comments from the comparison between the failure of Resona and the one of Ashikaga. First, market participants perceive the Takenaka Plan as a too-big-to-fail policy only in the first event of the release of that plan. Second, the market perception to deferred tax assets differs quite a bit between events of 2002 and 2003. In the two events that occurred in 2002, DEF is not significant. As of 2002, market participants do not seem to perceive that the government forces banks 


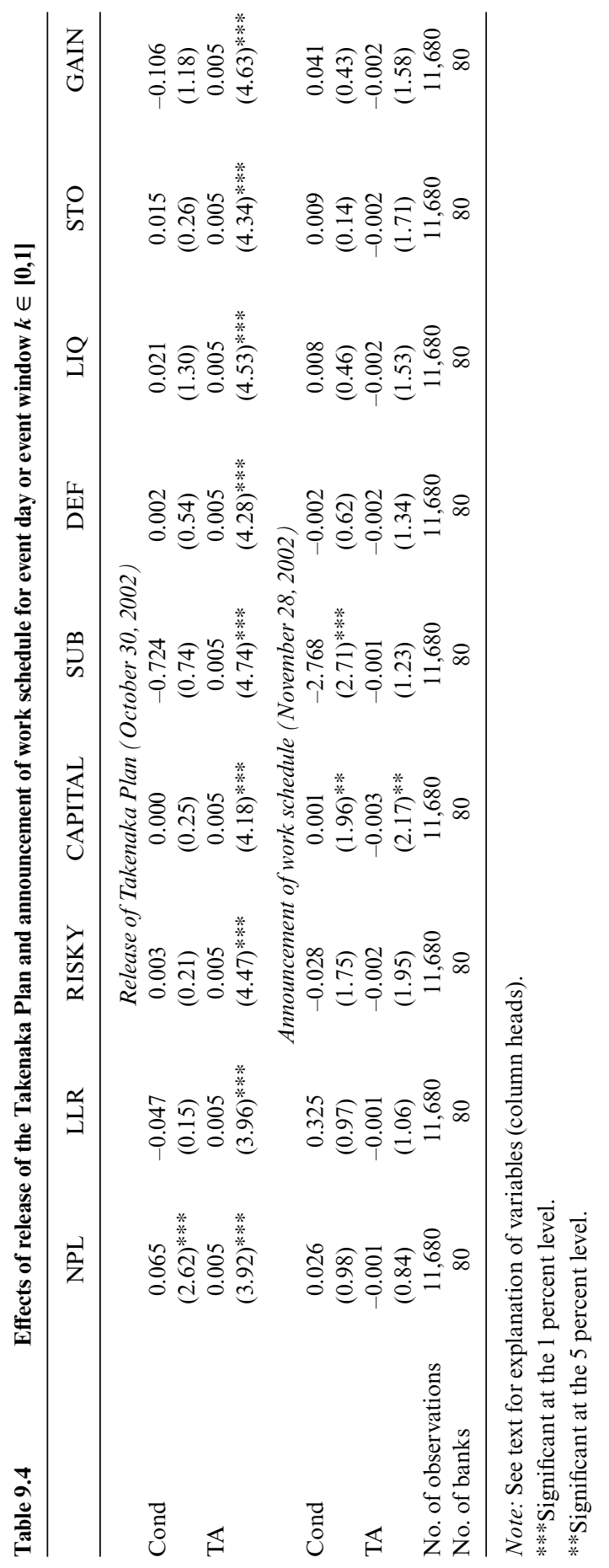


to stop regulatory-capital arbitrage using deferred tax assets. Third, the market evaluation on the Takenaka Plan varied over time. Among financial conditions, the number of significant coefficients monotonically increases over time, from zero (Release), to two (Work Schedule), further to four (Resona), and finally to five (Ashikaga). Market participants seem to change their expectation gradually on the implementation of the financial reform. Particularly, the credibility to the Takenaka Plan drastically increases in the latter two. The turning point may be the failure of Resona in which the government nationalized Resona by not allowing Resona to overestimate differed tax assets as bank capital. Another applicant may be the monetary policy that played a role of guaranteeing the implementation of the financial reform.

We next turn to the Resona event. There is much controversy on the government's statement for the protection of the existing shareholders following nationalization. Some observers stress this statement as a revival of forbearance. Yamori and Kobayashi (2007) report that in their estimation for the event day of May 21, 2003, the bank size has a significant effect on the stock market return, and conclude that the government's statement for the protection of Resona shareholders seem to have induced market participants to perceive the nationalization as a too-big-to-fail policy.

We estimate equations (2) through (9) using May 21, 2003 as an event day. If market participants perceive the nationalization of Resona as a toobig-to-fail policy, the log of total assets, denoted TA, should have a positive and significant coefficient.

Table 9.5 reports estimation results for equation (3), (4), and (5). The

Table 9.5

Abnormal returns of surviving banks for the statement for protection of Resona shareholders

\begin{tabular}{lccc}
\hline & Day 0 & Day +1 & {$[0,+1]$} \\
\hline The government announcement & to protect & shareholders & of Resona $($ May 21, 2003) \\
Simple mean & 0.011 & 0.007 & 0.009 \\
$t$-statistic & $1.43^{*}$ & $1.75^{* *}$ & $1.68^{* *}$ \\
Weighted mean & -0.018 & -0.001 & -0.010 \\
$t$-statistic & $-2.15^{* *}$ & -0.27 & $-1.54^{* *}$ \\
Median & -0.004 & 0.002 & -0.004 \\
Positive & 25 & 45 & 25 \\
Negative & 55 & 35 & 55 \\
Sign-test; $z$-statistic & $-2.93^{* *}$ & $2.24^{* *}$ & $-4.37^{* * *}$ \\
$H_{0}: \gamma_{1}=\ldots=\gamma_{80}$ & $1.34^{* *}$ & $2.06^{* * *}$ & $3.41^{* * *}$ \\
$F$-statistic & $107.22^{* *}$ & $165.34^{* * *}$ & $272.77^{* * *}$ \\
$\chi^{2}$-statistic & & & \\
\hline
\end{tabular}

*** Significant at the 1 percent level.

**Significant at the 5 percent level.

*Significant at the 10 percent level. 
first row, denoted "Simple Mean," reports that the average of the individual abnormal returns is positive and significant in any of the three windows. On the contrary, the results on "Weighted Mean" report that the average is negative in any of the three windows and significant for Day0 and the $[0,+1]$ window. This result may reveal that stock prices of small and regional banks rose, but those of large banks declined. Market participants do not perceive the statement for the protection of existing shareholders as a too-big-to-fail policy.

Table 9.6 reports the estimation results. The variable SUB is positive and significant, while it is insignificant in the estimation of May 19 to 20, 2003 (see table 9.2). Market participants seem to perceive the statement for protection as a revival of a forbearance policy. The variable $\mathrm{SH}$ is positive, and the $t$-values of the coefficient improve relative to the estimation of May 19 to 20,2003. This result is contrasted with the case of Ashikaga in which SH is negative and significant. The contrasting result between the two will reflect the different attitude of the government toward bank shareholders. The variable TA is insignificant in all of the estimations. We do not find any result to support the too-big-to-fail policy.

Our estimation differs from Yamori and Kobayashi (2007) in three respects. First, as a measure of bank size, they use a dummy variable that takes unity if the total asset of a bank is larger than that of Resona and zero otherwise, while we use the log of total assets. Second, they control for three variables representing the financial condition of banks, CAPITAL, NPL, and DEF in our definition, while we use more variables including SUB and RISKY. Third, we use the variable SH to control for the exposure of a bank to the failed bank through equity holding.

\subsection{Conclusion}

Using event-study methodology, we study how the stock market evaluates the Japanese financial reform, the Takenaka Plan that started in October 2002. We investigate several financial events that occurred in 2002 and 2003, including the release of the Takenaka Plan, the announcement of the work schedule for implementing that plan, the release of a package of monetary policies, and the failures of Resona Bank and Ashikaga Bank. Market participants came to perceive gradually that the government appropriately implements the Takenaka Plan in an attempt to improve bank governance. The credibility of the reform seems to have increased after the events that occurred in 2003, the failures of Resona and Ashikaga. In these estimations, bank shareholders differentiate individual banks by their financial conditions. This suggests financial supervision seems to have improved to some extent. Monetary policy also played an important role. The turning point may be the failure of Resona, in which the government nationalized Resona by not allowing Resona to overestimate differed tax 


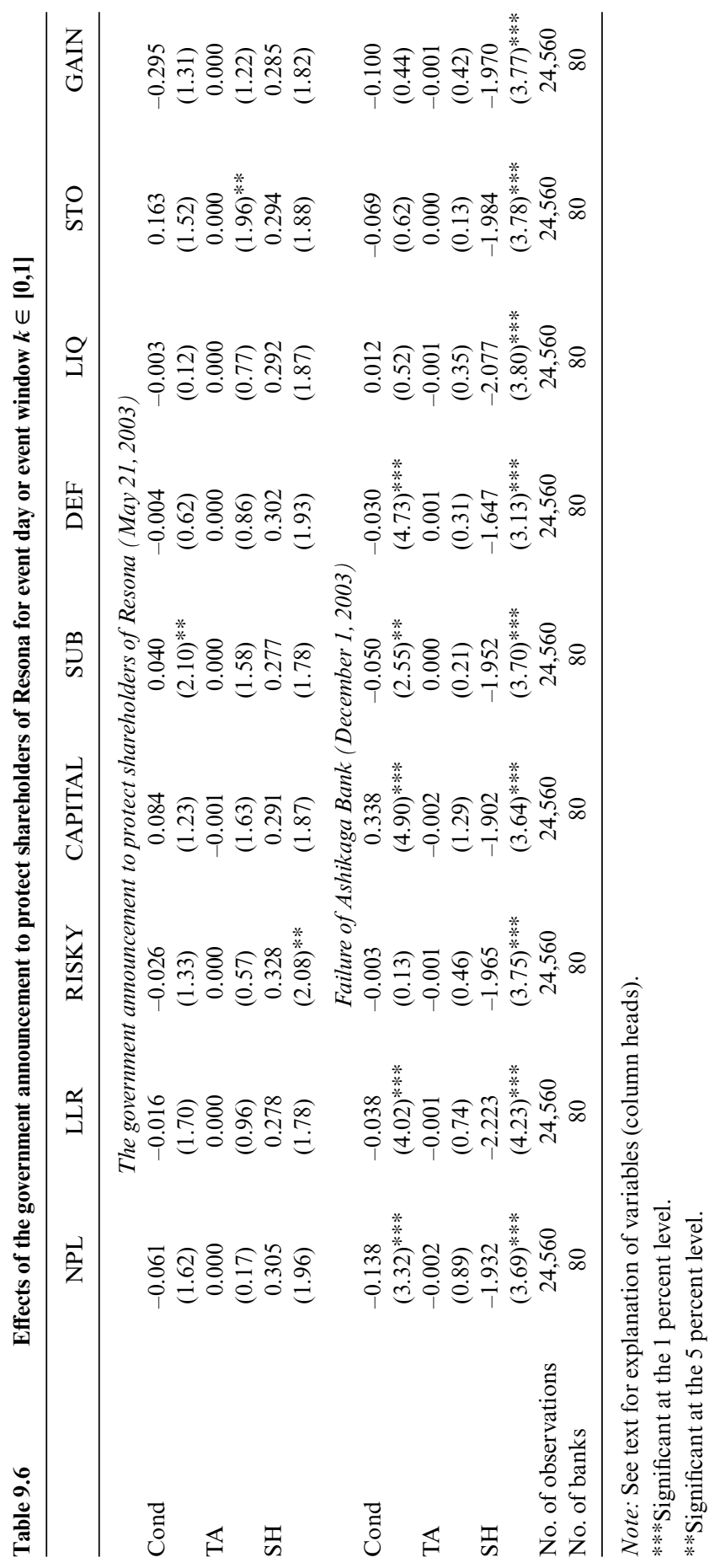


assets as bank capital. Another applicant may be the monetary policy that played a role of guaranteeing the implementation of the financial reform.

\section{References}

Brewer, E., III, and H. Genay, W. C. Hunter, and G. G. Kaufman. 2003. Does the Japanese stock market price bank-risk? Evidence from financial firm failures. Journal of Money, Credit and Banking 35 (4): 507-43.

Caballero, R. J., T. Hoshi, and A. K. Kashyap. 2003. Zombie lending and depressed restructuring in Japan. Paper presented at the NBER/CEPR/CIRJE/EIJS Japan Project meeting, Tokyo, Japan.

Fukao, M., and TCER. 2003. Kennsyo Ginnko Kiki-Suuti ga Simesu Keiei Jittai (Evidence of quantitative effects of the banking crisis). Tokyo: Nihon Keizai Shimbun-sha.

Hoshi, T. 2000. Naze Nihon ha Ryuudousei no Wana kara Nogareraretanoka? (Why didn't Japan escape from the liquidity trap?). In Zero Kinri to Nihon Keizai, ed. M. Fukao and H. Yoshikawa. Tokyo: Nihon Keizai Shimbun-sha.

Hoshi, T., and A. K. Kashyap. 2004. Japan's financial crisis and economic stagnation. Journal of Economic Perspective 18 (1): 3-26.

Hosono, K., and M. Sakuragawa. 2002. Soft budget problems in the Japanese credit market. Nagoya City University, Discussion Paper.

Ito, T., and K. Harada. 2004. Credit derivative premium as a new Japan premium. Journal of Money, Credit and Banking 36 (5): 965-68.

Ito, T., and Y. N. Sasaki. 2002. Impacts of the Basel capital standard on Japanese banks' behavior. Journal of the Japanese and International Economies 16:372-97.

Peek, J., and E. S. Rosengren. 2001. Determinants of the Japan premium: Actions speak louder than words. Journal of International Economics 53:283-305.

2005. Unnatural selection: Pervasive incentives and the misallocation of credit in Japan. American Economic Review 95:1144-66.

Sakuragawa, M. 2002. Kinnyu Kiki no Keizai Bunseki (The economic analysis of the financial crisis). Tokyo: Daigaku Syuppannkai.

Shrieves, R. E., and D. Dahl. 2003. Discretionary accounting and the behavior of Japanese banks under financial duress. Journal of Banking and Finance 27:121943.

Skinner, D. J. 2005. The rise of deferred tax assets in Japan: The case of the major Japanese banks. University of Chicago, Graduate School of Business, Working Paper.

Spiegel, M. M., and N. Yamori. 2003. The impact of Japan's financial stabilization laws on bank equity values. Journal of the Japanese and International Economies $17: 263-82$.

. 2004. The evolution of bank resolution policies in Japan: Evidence from market equity values. Journal of Financial Research 27 (1): 115-32.

Yamori, N., and A. Kobayashi. 2007. Wealth effect of public fund injections to ailing banks: Do deferred tax assets and auditing firms matter? Japanese Economic Review 58 (4): 466-83. 